\title{
Lessons for blue degrowth from Namibia's emerging blue economy
}

\author{
Rosanna Carver ${ }^{1}$ (D)
}

Received: 28 February 2019 / Accepted: 31 October 2019 / Published online: 23 December 2019

(c) The Author(s) 2019

\begin{abstract}
Globally there has been recognition that there is little consensus attributed to the definition of the blue economy. However, despite this acknowledgement, the blue economy is championed for its development potential by the African Union and subsequently, several African states. Having formalised the agenda in its fifth National Development Plan Namibia is working to implement a governance and management framework to "sustainably maximise benefits from marine resources" by 2020 (Republic of Namibia in Namibia's 5th National Development Plan (NDP5) 2017). Concurrently, new entrants, such as marine mineral mining projects, have emerged in recognition of the potential offered within the state's Exclusive Economic Zone. This article argues that the uptake of the blue economy is shaped by multiple, and often conflicting, interests. The emergence of the agenda is not apolitical, nor has it been established in isolation from exogenous actors and interests. Subsequently, this article suggests that the critique of the emerging blue economy should be applied to discussions of a blue degrowth movement, to avoid transposing a new agenda over another. As demonstrated with reference to Namibia, contextual and historical issues need to be recognised by degrowth discussions, and their inherent and continued structural effects analysed. This is of particular importance when considering whose voices are represented or excluded by such agendas, complicated by the (geo)physical characteristics of the marine sphere.
\end{abstract}

Keywords Degrowth $\cdot$ Blue economy $\cdot$ Namibia $\cdot$ Seabed mining $\cdot$ Blue degrowth $\cdot$ EEZ

\section{Introduction}

The blue economy agenda builds on development rhetoric and is professed to sustainably utilise ocean resources for economic growth without compromising the health of the ecosystem (World Bank 2017a). Describing the potential contribution to human wellbeing provided by oceans, the agenda has variously become a guiding frame, policy discourse and set of practices across the globe (see Editorial). However, at the same time and with limited exceptions (see Winder and Le Heron 2017), there has yet to be a sustained critical analysis which draws upon the fact that blue growth is simultaneously a socio-economic, and biological project with corollary complexities.

Handled by Maria Hadjimichael, University of Cyprus, Cyprus.

Rosanna Carver

r.carver@lancaster.ac.uk

1 Lancaster Environment Centre, Lancaster University, Lancaster LA1 4YQ, UK
Given that the blue economy has begun to gain traction in several states (van Wyk 2015: 154), a critical and empirical analysis of the agenda is imperative. Blue growth discourse legitimises the involvement of new entrants in the marine scape, but also excludes and marginalises certain actors. However, this recognition, or disregard, of different voices is not inadvertent: it serves political and economic interests in the marine scape. By analysing the emergence of the blue economy in Namibia, this paper argues that the uptake of the agenda is shaped by multiple, and often conflicting, interests. In considering the exogenous origin(s) of the blue economy agenda, this paper argues that its transposition-by which external concepts are imposed over a space where the state has sovereign rights in a way that (continuously) opens, (re)articulates and closes the marine scape-is not only an inherently political action but has also resulted in new political challenges in Namibia. These observations should also be acknowledged in the emergent discussions of blue degrowth.

Despite being a relatively recent framework, the blue economy has been incorporated into the AU's 2050 
Integrated Maritime Strategy and the Union's fifty-year strategy, Agenda 2063, which aims to accelerate the continent's development and achieve socioeconomic transformation (African Union 2014:6). This uptake is echoed at the national level, exemplified by the Republic of Seychelles' codification of the blue economy's role in its future development (GLISPA 2018) and Mauritius's initiation of policies to increase engagement with the economic potential of this emerging frontier (UNECA 2016). Ruppel and Biam argue that this development reflects the AU's desire for the ownership and "Africanisation" of the region's maritime affairs (Rupple and Baim 2016: 1), building on the continent's earlier success in international negotiations, including the United Nation's Convention on the Law of the Sea (UNCLOS) III (Suárez-de Vivero 2013). However, this is an oversimplification that ignores the complexities of the blue economy agenda and questions over who defines the concept.

While the concept of the blue economy is relatively new in the field of global environmental governance, the potential of the ocean space is increasingly relevant to coastal states looking to benefit from their waters. Interests in the marine environment are not limited to traditional industries and conservation. Globally, interest in seabed mining is emerging, given the discovery of "scarce" and in demand minerals such as cobalt and phosphate. These marine minerals are professed to offer the potential for economic development (Barbier 2012: 110; World Trade Organisation 2010). ${ }^{1}$ However, this rational is an oversimplification. That there is a direct correlation between scarcity, demand and the market value of minerals is contested (Klinger 2018a, b).

Namibia is one of the first states on the African continent to be considering the potential for seabed mining and is concurrently formalising its blue economy (which explicitly refers to marine mining). ${ }^{2}$ In (re)defining the ocean, seabed mining has been central to discussions due to the unique upwellings of the Benguela Current Ecosystem which in turn have led to the accumulation of marine phosphate. Speaking at the Sustainable Blue Economy Conference in 2018 Saara Kuugongelwa, Prime Minister of Namibia, informed participants that Namibia is developing sustainable seabed mining (SBEC 2018). The potential of these minerals, and their imagined contribution to a vision of development, accords with the United Nations Economic Commission for Africa's statement that, "another Africa [exists] under the sea" (Lopes 2016). Here the sea is framed as a space that

\footnotetext{
1 This includes in countries such as Japan who have commercially exploited zinc and Papua New Guinea and Namibia who are currently negotiating exploitation in their Exclusive Economic Zones (EEZs).

${ }^{2}$ For further discussions of global seabed mining projects see Sammler (2016).
}

offers promise and can be harnessed by African states under the agenda. However, while rhetoric speaks of now sovereign states looking towards "another Africa", there is need to question the origin and implications of such strategies.

Despite its proclaimed potential, marine phosphate has engendered protestation due in part to the involvement of external actors and fears of environmental degradation and negative social effects, particularly to the livelihoods of those employed in Namibia's industrial fishing industry. ${ }^{3}$ These concerns have also been referenced by the degrowth movement, which argues that seabed mining will exceed the carrying capacity of the ocean ecosystem (Hadjimichael 2018). The contestation from a multitude of actors over seabed mining in Namibia and the lack of internal coherency about the blue economy agenda, illustrate that a given state's desire for an idealised vision of sovereignty - where the state operates within their Exclusive Economic Zone $(E E Z)^{4}$ without the involvement or influence of external actors (Dodds 2012: 993) —is an oversimplification. The blue economy's framing as a technical challenge hides the origins of such agendas, in terms of both knowledge production and financing, as well as the divergent actors pushing for and benefiting from blue growth [see Bakker (2010), Li (2007) for further discussion of how rendering an issue as technical serves to depoliticise it]. As this article identifies, the ambiguity of a global definition for the blue economy has resulted in disparate conceptualisations at a local level. This affects how the blue economy is enforced and institutionalised into policy and can result in an uneven articulation of the agenda.

In offering critique of the divergent and sometimes discordant interpretations of blue growth, this paper also acknowledges recent calls for a blue degrowth agenda (see Hadjimichael 2018). Degrowth aims to critique traditional ideas of growth and sustainability by encouraging an equitable reduction in production and consumption, alongside a socially transformative vision. Building on this, predominantly terrestrial, vision, Hadjimichael has argued that there is need for a "blue" degrowth concept, one which offers an alternative to current economic centric policies in the ocean (Hadjimichael 2018: 163). In recognising this call, this paper draws on the emergence of the blue economy in Namibian to suggest that discussions of (blue) degrowth in this special issue, and elsewhere, must be introspective.

\footnotetext{
${ }^{3}$ Given Namibia's dynamic and inhospitable coast, it is important to note that there is limited documented artisanal fishing in Namibia. Small-scale fishing is also limited to subsistence or recreational fishing (Belhabib et al. 2016).

${ }^{4}$ A state's EEZ extends up to 200 nautical miles from the territorial sea baseline. It is not formalised as "territory"-territorial waters only extend to 12 nautical miles.
} 
The first section of this paper will outline the methodology and provide context to the Namibian case study. It will then discuss the establishment of the blue economy in relation to the green economy, exploring the beginnings of the blue economy in Namibia. Third, this paper will focus on the potential for seabed mining, to analyse the structural and contextual issues that have transpired from the formalisation of blue economy agenda. Finally, some of the lessons that have emerged from Namibia's experience will be applied to the emergent discussions of (blue) degrowth.

\section{Methodology}

Focusing on Namibia's emergent blue economy, this article draws on debates of the potential for extraction of marine phosphate which are evaluated in combination with materials from the author's three periods of fieldwork in Namibia from 2016, 2017 and 2018. Over a 3-year period, in-depth semi-structured interviews were conducted with key actors involved in Namibia's marine space. Interviewees included representatives from the fishing and mining industry, NGOs and INGOs, formalised civil society organisations and ministerial officials. Due to the close-knit nature of relations between elite actors involved with Namibia's marine environment, anonymity was offered to all participants and was selected without exception. Consequently, interviewees' names and job titles have been removed from this paper. These interviews have been analysed alongside policy discourse, including National Development Plans, legislative acts and INGO strategy documents, to critically examine the divergent and often competing definitions of blue growth.

\section{Context to the Namibian case study}

Colonised initially by Germany in 1884 , what was then referred to as South West Africa was subsequently governed through South African mandate rule from 1920 to 1990. While under South African control apartheid rule was transposed over the country, thus restricting the political and socio-economic freedoms of black Namibians (Melber 2014). Namibia's colonial period was also characterised by exploitation both in terms of minerals-including diamond mining off the coast-and fish [Namibia experienced overexploitation of its fish stocks under South African mandate rule (Sjöstedt and Sundström 2015: 80)].

Following Namibia's independence in 1990, structures pertaining to colonial rule have remained despite attempts to redress previous exploitation, and Namibia is highly dependent on mineral extraction. In the marine sphere, initiatives such as Namibianisation have sought to rectify colonial overexploitation and exclusion by ensuring that Namibians are the majority shareholders of fishing companies whilst promoting job creation and income generation for the government (Erastus 2002: 43). However, the policy's success has been challenged (see Melber 2003): a challenge that was reflected by a fishing industry representative who explained, "we don't have the capacity at all to run fishing. It hasn't been built up since independence. No one has invested in the infrastructure that is needed." ${ }^{5}$ Despite the illusion of Namibian ownership, the mergers and consolidation of the industry that has taken place since Namibianisation have resulted in the majority of fishing quotas being controlled by a small number of de facto owners, including those with direct or indirect relationships to political figures (Melber 2014; 120,121). Without redressing the inherent structural bias(es), industrialised and often foreign-owned fisheries continue to dominate the industry. This dominance of industrial fishing has a corollary impact upon discussions of blue degrowth, the challenges of which are unpacked in the subsequent sections.

Namibia's colonial experience, and the resultant complex relationships that exist today, have in turn influenced the implementation of policies in Namibia's marine space. ${ }^{6}$ The continued involvement of external actors is evident, particularly given that Namibia is currently in recession (Nyaungwa et al. 2018). International organisations and NGOs, including GIZ, the German development agency, are integral to the dissemination of the blue economy and Marine Spatial Planning (MSP) - a tool to promote the blue economy through planning and mapping. ${ }^{7}$ This remapping involves a range of actors who in turn are "assembling networks and making territories around specific [and potentially incompatible] projects" (Winder and Le Heron 2017: 20; see also Müller 2015). The fact that GIZ represents a country that previously colonised Namibia, coupled with the ongoing critique of continued German involvement in Namibia, calls into question the potential erosion of democratic rights and context(s) within which knowledge(s) are created. These persisting structural inequalities are unpacked in this paper and are crucial reflections for discussions of (blue) degrowth.

\footnotetext{
5 Industry representative, Walvis Bay, Namibia, 2017.

${ }^{6}$ Umbrella organisation representative, Windhoek, Namibia, 2017; NGO representative, Swakopmund, Namibia, 2017; Consultant, Swakopmund, Namibia 2017.

7 As with definitions of the blue economy, MSP evades definition leaving it open to interpretation as a developmental tool to mediate overlapping uses within the sea space, or as a tool to ensure that the oceans biological integrity is not compromised (Gazzola et al. 2015: 1157). See Boucquey et al. (2016) for further discussion of MSP.
} 


\section{Bluing the green}

Comparable to the concept of the green economy, which emerged in the international policy arena at the Rio+ 20 United Nations Conference on Sustainable Development, the blue economy responds to calls for a "new economic paradigm" that encompasses growth and environmental concerns (this argument has also been made in relation to the green economy; see Wanner 2015: 22). Much like the green economy before it, the blue economy (and within it, blue growth) is presently accepted as the foremost solution to environmental degradation positioned under the auspices of sustainable development and poverty alleviation priorities, with the environment defined as a key driver of economic growth (similarly, for discussions relating to the green economy, see UNEP 2011). This commodification of nature and promotion of increased market access assumes to address concerns arising from an absence of clarity over the ownership of resources. This rationale is reflected by development rhetoric that sees the United Nations Environment Programme argue that "people lack the incentive to manage [resources] well" without financial motivation (2008: 565).

The green economy's commodification of nature has, however, been challenged by scholarship (see Brand and Wissen 2012; Goodman and Salleh 2013 and Khor 2011). The agenda has been accused of acting not to bring an end to the neoliberalisation of capitalist society, but to be an extension of it (Wanner 2015: 24) due to its prioritisation of economic dimensions which serves to mask the political and social dimensions of sustainability (Brand and Wissen 2012: 28; Wanner 2015: 28). This view is shared by Martin Khor who argues that the green economy depoliticises sustainability and does not address the structural causes of economic inequality and poverty (Khor 2011), and these criticisms would arguably be applicable to the blue economy as well.

The green economy has been publicly supported by the Namibian government (Faccer et al. 2014: 653) and Namibia's terrestrial approaches within this transition have been praised by environmental INGOs (WWF 2013). Approaches such as Community-Based Natural Resource Management (CBNRM), where revenue is increasingly derived from international tourism and the practice of trophy-hunting, draw on market-based conservation (Lapeyre 2011; Naidoo et al. 2016). However, CBNRM projects have been criticised for moving knowledge and decision-making processes away from communities to external tourism demands and (usually larger and international) NGOs (Sullivan et al. 2016).

Conflicting definitions of the green economy have arisen, including those which encompass the social, ecological and economic aspects of sustainable development and those who more dualistically emphasise the relationship between humanity and nature (see Gibson 2002). As with the blue economy, the definition of sustainable development remains vague with the Brundtland report's definition remaining the most cited (Stoddart 2011). The conflict that these differing interpretations engenders is visible in Namibia, and the performative elements of the green economy have been criticised for prioritising global agendas over local responses (Sullivan et al. 2016).

As the ocean is variously framed under a multitude of agendas (Abbott et al. 2014) there is a need to ensure that attention is given to the institutional contexts and discourses that constitute the blue economy and its conception (Silver et al. 2015: 138; see also Steinberg 2008). Due to increasing interest in the potential of Namibia's sea including, but not limited to, those advocating for conservation and development agendas (Abbott et al. 2014; Campbell et al. 2013), discourse(s) of commodification of the global oceans have emerged. Here the concept of blue growth acts as a justification for the continuation of capitalist expansion, this time into the sea. As seen in the case of the green economy, but relevant also to discussions relating to the blue economy, conceptualisations of nature and its resources as commodities, with development potential, are being institutionalised by multilateral organisations including conservation-based INGOs (Corson 2010; Fairhead et al. 2012: 244). Goodman and Salleh observe that the green economy is a concept "waged across several dimensions, engaging both state and non-state actors" (Goodman and Salleh 2013: 412), and it can be argued that the same is now occurring in relation to the sea, raising questions as to who is defining the blue economy. This is particularly pertinent given that the depletion of onshore minerals, alongside technological advances, has led to a resurgence of interest in the exploration and exploitation of reserves located in the seabed (Morrissey 2017; see also Morrissey et al. 2011; Stojanovic and Farmer 2013; Zhao et al. 2014).

Despite recognition of the wealth of marine minerals, including in Namibia's EEZ, discussions of the blue economies of African states have focussed on the continent's fisheries and conservation priorities, with scant reference to the emerging marine based mineral extraction. However, the blue economy enables actors to bring in previously (and traditionally) competing discourses under a development agenda. While the definition of the blue economy is divisive in terms of its semantics, distinguishing between the sea and land, state and non-state actors have interpreted it as inclusive in terms of marine activities. Formalised in 2017 in Namibia's 5th National Development Plan (NDP5), its EEZ and by extension, blue economy, is credited for its ability to "significantly contribute to [Namibia's] economic transformation agenda" through key industries including, but not limited to, fishing, tourism and seabed mining (Republic of Namibia 2017: 24). While the NDP5 does not provide a succinct definition of the blue economy, its conceptualisation is inherently economic. Namibia's EEZ is described by 
the State as a space which "provides valuable goods and services" and is "an important resource for tourism, fisheries, transport and logistics as well as mining" (Republic of Namibia 2017: 24).

The inclusive nature of the blue economy's definition has marred the implementation of the agenda on the ground: with questions pertaining as to what the agenda professes to offer and whose interests it represents. For many in Namibia, including ministerial representatives and those involved with environmental umbrella organisations, the blue economy holds little to no meaning at all, and this introduces a challenge to the idea of a locally-owned and -directed agenda. A key civil servant involved in the formalisation of the blue economy in Namibia explained during an interview: "I don't understand what the blue economy is." 8 This lack of clarity over the concept was echoed by those involved in the governance of the marine space. A ministerial representative highlighted the lack of certainty over definitions of the agenda: "I first heard about the green economy and then the blue. It was at a UN conference. Then I was confused. What does this mean?" Here, the disparate global definitions of the blue economy have led to an absence of clarity over what this agenda means to Namibia and how it will be consolidated within policy.

The fact that the blue economy has little meaning in Namibia contrasts with the African Union's rhetoric on African ownership of its maritime domain and the policies entailed therein. Conceptualisations of nation states' permanent sovereignty over the maritime domain were enacted during the process of ratifying UNCLOS III wherein national sovereign rights were extended and codified in legal terms over maritime space (Adar 1987: 666; Suárez-de Vivero 2013). The consolidation of this principle was an attempt to control the overexploitation that occurred during colonialism, with newly independent nations seeking to consolidate permanent sovereignty over their natural resources based on self-determination (Schrijver 1997: 228). As such, developing states emphasised that this extension of rights enables preservation over this space that they did not have the capacity yet to enforce or exploit (Suárez-de Vivero 2013). However, the lack of understanding of the blue economy within Namibia itself highlights that African states' ownership of the marine domain is not antagonistic to external actors. Rather, the agenda and associated rhetoric are being transposed over the marine sphere including by non-state and external actors.

\footnotetext{
${ }^{8}$ Ministry representative, Windhoek, 2016.

${ }^{9}$ Ministry representative, Windhoek, 2017.
}

\section{Divergent definitions}

The generalised lack of consensus over a global definition of the blue economy has engendered varying articulations that exist across competing discourses (Winder and Le Heron 2017: 5; see also Silver et al. 2015). As Hadjimichael (2018) argues, this profusion of definitions serves to constrain the agenda. However, this multiplicity of definitions is also evident at the national and local scales in Namibia. The saturation of and incoherence between these definitions not only serves to constrain the agenda but leaves it open to influence or manipulation by various actors in countries where the agenda is being formalised, particularly during the early stages. Where there is familiarity with the concept in Namibia, the lack of consensus over the blue economy's definition remains apparent.

While the NDP5 speaks of a blue economy that capitalises on, and equitably distributes, the economic benefits of its EEZ and resources therein (Republic of Namibia 2017), key actors (those directly involved in the formalisation or implementation of the blue economy) hold various and sometimes dichotomous definitions to be true. Given actor's preferred definitions are often dependent on the industry that they represent(ed) or are/were otherwise involved with. For example, mining industry representatives spoke of economic potential and explained that the blue economy had been introduced to them as a means of "getting resources out of the sea." ${ }^{10}$ However, representatives of the fishing industry spoke of a blue economy that prioritises sustainability and protection of Namibia's EEZ - a prioritisation that they view as incongruous with activities such as seabed mining. Similarly, local development NGOs understood the blue economy to be a strategy through which the social-economic potential of the ocean could be realised, but explained that associated activities must not deplete the ocean. Environmental NGOs, on the other hand, spoke of the need to recognise the protection of biodiversity as a priority. This ambiguity over definitions reduces Namibia's marine environment to a space, which actors can exert influence over and apportion in accordance with their own agendas, leaving the blue economy as a concept merely utilised to justify emerging projects.

Namibia's blue economy is variously framed by actors as a development opportunity, a conservation space, the dominium of the fishing industry and/or as an empty and emerging frontier, as seen with marine phosphate, that can be shaped "as a resource for exploitation... a gold mine." ${ }^{11}$ This framing supports not only actors who already operate within this space, but new entrants including marine mineral mining

\footnotetext{
${ }^{10}$ Industry representative, 2017.

${ }^{11}$ NGO representative, Cape Town, South Africa, 2017.
} 
projects who are competing to operate within this space. However, this divergent framing has been met with resistance from formalised civil society organisations who have labelled the agenda as "half-baked" 12 and criticised its focus on industrial exploitation. The fact that the concept means different things to different people and industries implies that we must analyse the ownership of knowledge and the diverging interests that currently inform marine policies. An NGO representative explained that while they had heard of the blue economy in 2012, it was not until 2016 that the agenda appeared in the Namibian government's discourse. Despite the government utilising the terminology and formalising the concept in the years since, there remains little consensus over the definition with the NGO representative explaining that they "have heard of it in terms of whatever fits at the time" ${ }^{13}$ : its uneven and ambiguous definitions resulting in the agenda being understood in multiple ways. This ambiguity has left space for contentious projects such as marine mineral mining to enter the EEZ.

Although there has been scholarly recognition that the concept of the blue economy lacks a uniform interpretation, there has been little engagement with the consequences of this fact (see Winder and Le Heron 2017: 10). While government officials in Namibia cite the blue economy as a means to unlock the country's economic potential, thus moving away from their traditional reliance on its land, ${ }^{14}$ civil society organisations have warned of the implications if the blue economy is used as an indiscriminate justification for projects in the marine sphere. Framing the sea as a development opportunity enables new entrants such as extractive industries to access the marine space, despite the ambiguities of the potential outcomes of such projects remaining contentious. This proliferation of current and new users is also challenged due to the physical properties of the ocean, its three-dimensional and fluid characteristics complicating the ability to divide the space for different uses. Competing activities in the blue economy cannot be easily demarcated, and ownership ascribed. These challenges are evident in Namibia where the consideration of marine phosphate mining is engendering concern from traditional industries (including, importantly, fishing) that operate within this space (see Carver 2019).

Divergent definitions of the blue economy also exist at both inter- and intra-agency levels in Namibia. The dynamic marine space encompasses a multitude of overlapping uses, often administered by multiple ministries (Winder and Le Heron 2017: 4; see also Arkema et al. 2006; Ban et al. 2014). However, when the agenda was institutionalised,

12 NGO representative, Windhoek, Namibia, 2017.

13 NGO representative, Windhoek, Namibia, 2017.

14 Ministry representative, Windhoek, Namibia, 2017. the Ministry of Fisheries and Marine Resources (MFMR) was appointed as the overseeing ministerial department. While this ministerial jurisdiction appears logical, the blue economy offers justification for a multitude of projectsincluding fishing, tourism and mining-particularly those with an (economic) development purpose. The governance of such projects therefore sits across different ministerial remits including, but not limited to, the MME, the Ministry of Environment and Tourism (MET) and the Ministry of Works and Transport (MWT) who each have disparate interactions with the agenda and seabed mining. Despite overlapping responsibilities, that are particularly pronounced in the marine scape, ministries have been accused of not engaging in open dialogue, acting in isolation. ${ }^{15}$

The formalisation of the blue economy agenda has also highlighted (geo)spatial limits of ministerial jurisdictions. The area up to the low-water mark pertains to MET and from the high-water mark, MFMR. Ministerial authority is therefore blurred within the area between the low-water and high-water mark. While MET retains responsibility for environmental clearance certificates, including for marine-based mining, the department has limited coastal research staff beyond ornithologists and zoologists. These (geo)spatial issues are also evident with regards to highly mobile-species, with sea birds falling under the MFMR's responsibility even though they breed on land. ${ }^{16}$ These already complex grey zones are exacerbated by potential blue growth developments, because, unlike with the green economy, blue growth projects may not accord to this stratified approach to spatial governance.

There are potential wider implications of fragmented ministerial jurisdictions. Questions are being raised regarding the monitoring and governance of activities that fall under the blue economy remit, with ministries and industries alike asking where this responsibility lies, particularly considering seabed mining projects. Data is not readily shared between, or within, ministries and MFMR are the only ministry with access to vessels to monitor projects within the marine sphere. ${ }^{17}$ The incoherence around the agenda, coupled with the associated ministerial fragmentation, as well as the lack of supporting structures required to enable the navigation of such formalisation, indicates that Namibia's level of control over is blue economy agenda could be classed as "functional ownership" as opposed to "structural ownership" (see Perry and Keil 2013: 375 for discussions of local ownership). Functional ownership may involve local actors in the implementation of projects or the allocation of funding, but the involvement in the planning

\footnotetext{
15 Ministry representative, 2018.

16 Ministry representative, Swakopmund, Namibia, 2017.

17 NGO representative, Windhoek, 2017.
} 
stage is limited. However, structural ownership involves a more embedded form of engagement with local actors (Perry and Keil 2013: 375). That Namibia's structural ownership is limited, highlights potential challenges to its ownership of the blue economy agenda.

\section{A blue economy for whom?}

The absence of a unified definition of Namibia's blue economy and questions of ownership over the concept illustrates the importance of not only analysing the discourse(s) related to the blue economy but also understanding the power dynamics embedded in the articulation of ocean space and its management. Several key actors stated that they had little interest in the concept, comparing it to the green economy and arguing that it was "another buzzword", ${ }^{18}$ coined externally, with little substance or reflection of Namibian agendas. In questioning the heterogeneity of approaches to the concept, it is therefore also important to ask where the knowledge and ownership of the concept originates from.

The nature of the interest in Namibia's EEZ and blue economy extends beyond the economic and the technical. Just as has been discussed with regards to the green economy's conceptualisations of nature being institutionalised by multilateral organisations (Corson 2010; Fairhead et al. 2012: 244), it can be argued that the same is occurring in relation to the ocean. This raises questions regarding who defines the blue economy. With the advent of "expectations from the UN Member States to bring management of their EEZs into line with international best practice" (Winder and Le Heron 2017: 9), countries are increasingly engaging with blue economy initiatives under the guidance of external actors, with their own political and economic interests.

While African states held a key position allowing them to influence negotiations during the UNCLOS (Egede 2014), it is the INGOs and international organisations that have been central to the formalisation of the blue economy in Namibia. These relationships entail deep political agendas (see Chalfin 2015: 113) which are being transposed onto Namibia's EEZ, thus eroding the rights that Namibia has over the resources (and their management) therein. Despite being classified as an upper middle-income country (World Bank 2017b), Namibia is still reliant upon donor support and grants, particularly during its current financial crisis. This transition has meant that Namibia is ineligible for several development assistance funds, and alternative sources of income are being sought. That the blue economy initiative is therefore of financial importance to Namibia was insinuated by a ministerial representative. However, these funding sources are embedded within (and contingent upon) the uptake of a neoliberal narrative offered by blue growth where economic

$\overline{18}$ Industry representative, Windhoek, Namibia, 2017. performance, as opposed to social or ecological welfare, is the driver (Hadjimichael 2018).

In Namibia, the UNDP has been involved in the financing of aspects of the blue economy agenda by supporting, alongside other development partners, the Benguela Current Commission, which is an inter-governmental initiative that manages the marine environment in the Benguela Current Large Marine Ecosystem. ${ }^{19}$ Given that the UNDP is the responsible UN agency in Namibia, their approach unsurprisingly focuses on development potential but with a sustainable narrative. The UNDP identify the importance of protecting and restoring the ocean, while also pursuing opportunities that "may exist for enhanced or new sustainable economic activity derived from the ocean." These opportunities are identified as fishing and offshore wind and tidal energy projects (UNDP 2018) but the UNDP does not specifically include or exclude seabed mining in its definition.

During the three-year fieldwork period of this study, key ministry representatives participated in conferences and workshops that were run by the European Commission, such as "Marine Spatial Planning 2017" in Paris which included items on the blue economy in its agenda. Several ministerial representatives, from MFMR and MET, explained that this conference was a pivotal moment for the blue economy's uptake in Namibia. This conference was co-organised by the Intergovernmental Oceanographic Commission of UNESCO and the European Commission, and its sponsors included GIZ, and other funding instruments of the German government. The EC, like the $\mathrm{AU}$, has an approach to the blue economy that is inherently focused on blue growth and economics, and that references the ocean's potential contribution to job creation, innovation and growth (African Union 2014; European Commission 2019). In contrast to the UNDP, the EC's strategy also specifically identifies seabed mining as one of the five sectors that the EU is aiming to develop due to its "potential for sustainable jobs and growth" (European Commission 2019).

Despite discourse suggesting that the blue economy is an opportunity for states to benefit from their marine scape in a way that was previously denied during periods of colonial exploitation, Namibia's international relationships also continue to replicate some of the dynamics observed during colonialism. Interviewees referenced South Africa's marine policies, particularly Operation Phakisa, explaining that they have encountered blue economy rhetoric in this context. ${ }^{20}$ Operation Phakisa is South Africa's blue growth strategy which aims to unlock the benefits offered by its

\footnotetext{
19 The Benguela Current Ecosystem extends from Angola in the North to South Africa in the South.

${ }^{20}$ Industry representative, Windhoek, Namibia, 2017; NGO representative, Swakopmund, Namibia, 2017; INGO representative, Cape Town, South Africa, 2017.
} 
ocean economy (Findlay 2018: 248). However, the delivery of this strategy has been accused by formalised civil society representatives in South Africa of being a development-centric project, which focuses on industrial operations like shipping, oil and gas. ${ }^{21}$ The perceived primacy of South Africa in Namibia's national imagination illustrates the embeddedness of the South African influence, which extends beyond the oft-cited tied currency to concrete policy ties. Interviewees argued that states in southern Africa are watching how the other states proceed with the agenda. ${ }^{22}$ Given that there are a multitude of definitions and interpretations of the blue economy it is of little surprise that confusion over a cohesive government or ministerial definition remains.

The absence of a uniform definition of the blue economy means not only that it has become malleable but that it is less critiqued by those who would traditionally have resisted such agendas such as conservation NGOs (see Hannigan 2016). In questioning whose voices are being reflected in the blue economy agenda, it is therefore also important to ask who is being excluded. Given the (geo)physical characteristics of Namibia's coast, exclusion is perhaps even easier to realise in the marine scape than terrestrially. This is due, in part, to the low levels of coastal inhabitants and the population's limited overall physical engagement with Namibia's marine environment. Exclusion is also perpetuated by a disenfranchisement of civil society on the coast and elsewhere. Several civil society actors also spoke of a generalised passivity that has been observed within Namibia following independence. They argued that there had been a move from collective struggle to individual struggles. ${ }^{23}$ This has manifested itself with the blue growth discourse, specifically with regards to marine phosphate mining. Civil society uptake of the issue is fragmented, and environmental NGOs have been accused by NGOs, with a socio-economic remit, of having too narrow a focus that overlooks practices of the fishing industry itself as well as ownership and labour issues. $^{24}$

Where there has been formalised civil society engagement with the ocean and the blue economy, interviewees, particularly those in the NGOs and development sphere, spoke of the lack of space for civil society in Namibia: a space that has been narrowing following independence (Melber 2014). The nature of the political environment presently

\footnotetext{
${ }_{21}^{21}$ INGO representative, Cape Town, South Africa, 2017.

22 Industry representative, Swakopmund, 2017; INGO representative, Cape Town, South Africa, 2017.

23 Umbrella organisation representative, Windhoek, Namibia, 2018.

${ }^{24}$ Umbrella organisation representative, Windhoek, Namibia, 2018.
}

makes it difficult to criticise the government, not least due to the absence of a credible political opposition. ${ }^{25}$ Highlighting issues related to the absence of Namibia's "capacity" to operate in the marine environment, umbrella organisations and civil society representatives spoke about the need to "build civil society" 26 to enable a more representative Namibian response to projects such as phosphate extraction. However, interviewees did not define what constitutes the building of civil society, and the traditional idea that civil society will hold the state accountable is problematic (Edwards 2004: 19). NGOs, which are often assumed to be the representative of civil society to the West, themselves often adhere to donor requirements and may serve other less obvious agendas besides. Furthermore, whilst a formalised civil society may be created, involvement in civil society is often the preserve of educated elites who are shaping agendas, and this challenges the extent to which Namibian civil society is representative of the Namibian public. The dominance of a "white voice" has also been raised by interviewees concerned that white elites have often been the most vocal within both the NGO space and through advocacy networks in Namibia, a resonance that extends to marine phosphate mining. These dominant voices also challenge how sovereignty over resources is enacted when an independent state's formalised civil society is not an ideal-type (Keane 1998: 6), but one that stands to shape the formalisation of marine policies in Namibia.

While the provenance of the agenda and involvement of international organisations has been discussed in this paper, contestation over Namibia's marine sphere is not directed solely towards the blue economy itself. The flexible approach taken by actors in interpreting the agenda, including its framing as a conservation agenda, has seen it garner support from a multitude of actors. In Namibia the absence of a uniform definition of the blue economy means not only that it has become malleable, but also that it is less critiqued by those who would traditionally have resisted such agendas. Conservation organisations have been accused of overlooking its economic dimensions and potential contestations. However, as previously discussed, this is not reflective of all actors' positions, and when interviewed, several formalised civil society actors argued that blue economy's professed sustainability is misleading.

The marine phosphate mining debate has encouraged observers to (re)focus on Namibia's marine policies, including the blue economy. While rhetoric around jobs and growth has been of central importance within arguments designed to legitimise the agenda and marine phosphate

\footnotetext{
${ }^{25}$ Umbrella organisation representative, Windhoek, Namibia, 2018; Analyst, Windhoek, Namibia, 2018.

${ }^{26}$ NGO, Windhoek, Namibia, 2017.
} 
mining, those voicing environmental concerns have counteracted them. Umbrella organisation(s) and NGO representatives, particularly those with an environmental focus, voiced concerns that Namibia's blue economy and interpretation of sustainable development were focused on economic growth as opposed to ecological concerns: with seabed mining offering an example of where development potential is superordinate to potential environmental impacts. ${ }^{27}$ The conflict over potential phosphate mining projects highlights the convergent interpretations of the blue economy and how these are being utilised to support competing agendas.

The contention over seabed mining in Namibia illustrates that the physical nature of the marine environment complicates divisions within this dynamic and boundless ocean space. For example, one interviewee voiced concerns in this regard: "The problem with the blue economy is that it's about who gets control so that they can exploit it for themselves and not for the benefit of the whole economy." ${ }^{28}$ Perceptions such as this indicate the divergent internal interests that exist within Namibia's marine sphere. These interests threaten the Namibian state's goal of sectoral harmonisation. However, despite these industries' integral collective role in shaping this space through capitalist agendas, to reduce the blue economy to an arena where industries old and emerging alike are attempting to stake their claims would be overly simplistic. In doing so this would serve to draw attention away from where the agenda and rhetoric originate. In the case of Namibia this contestation goes beyond conflict between civil society and the mining projects, to encompass contention between the mining and fishing industries. However, while the fishing industry opposes offshore mining in Namibia, industrial fisheries are in themselves one of the industries and practices that the (blue) degrowth debate has challenged (see Hadjimichael 2018). It is to blue degrowth that this paper now turns.

\section{From blue growth to blue degrowth}

While the blue economy professes to offer an environmentally sustainable approach to growth, the degrowth agenda proposes different normative ideals. Those subscribing to the degrowth agenda argue that, by situating growth in a position central to socio-economic policies, these very policies will result in economic decline due to the finite nature of the Earth (Weiss and Cattaneo 2017). As Sandberg et al. (2019) discuss in relation to green growth, the blue economy is unlikely to slow or reverse environmental degradation.

\footnotetext{
${ }^{27}$ Consultant, Windhoek, Namibia, 2017; INGO representative, Windhoek, Namibia, 2017; Industry representative, Walvis Bay, Namibia, 2017.

28 Industry representative, Namibia, 2017.
}

The degrowth framework has therefore been offered an alternative to the green economy (Weiss and Cattaneob 2017), one that requires societal reorganisation and the reduction of consumption in developed countries (Chiengkul 2018). With origins in academia as well as social activist groups, degrowth builds on critiques of economic development to explore alternative forms of exchange, including reciprocity and redistribution (Martínez-Alier 2012).

While degrowth professes to identify an ecologically viable and equitable alternative to growth and economy policies, the concept remains underdeveloped. In recognising that at specific marine specific degrowth agenda has yet to be defined, this paper argues that the shortcomings raised in relation to the blue economy agenda should be considered as degrowth discussions develop. The degrowth movement, and the transformative change that it professes, has been criticised for ignoring the inherent hierarchical structures of global political economy, which in turn require reform at a global level to address the continuing inequalities within and between low income and upper income countries (Chiengkul 2018: 1). These inequalities are perhaps more pronounced when analysing the marine space: the (geo)physical characteristics of the marine environment-as a volumetric, three-dimensional and fluid space-mean that technological requirements, particularly for extractive projects, and data and knowledge pertaining to the seas, are typically consolidated in the hands of developed countries (Carver 2019. See also Childs 2018 for discussions of the dimensionality of seabed mining). Moreover, these inequalities are exacerbated when one considers the High Seas. ${ }^{29}$

National-level structural imbalances must be considered when addressing wage labour propositions by the degrowth movement (see Barca 2017). Namibia, for example, is faced with contexts where the opportunities to establish degrowth initiatives are comparatively limited. The lack of available jobs in Namibia, due to Namibia's recession and high unemployment rates on the coast reduces the propensity of individuals to take economic risks (see Chiengkul 2018: 10). Proponents of blue degrowth have argued that small-scale fisheries could offer an alternative source of income and these fisheries are often considered as potential allies for the movement (Pinkerton 2017). However, that Namibia is characterised by vast areas of uninhabited land and an inhospitable coast has resulted in an (almost) absence of artisanal and small-scale fisheries. This consolidates some of the risks, with individuals unable to move from employees of industrial fisheries to smaller-scale practices. As such,

\footnotetext{
${ }^{29}$ Lower income countries' voices have increasingly been side-lined and global imbalances in technological hard and soft capacity have the potential to affect the potential of their extractive capabilities in the High Seas [see Jaeckel et al. (2016), Sammler (2016)].
} 
the fishing and mining sector are perceived as integral. Furthermore, employment within these sectors is perceived as interchangeable in a way that employment in industrial and small-scale fishing is not. As a representative of the industrial fishing industry explained:

In the long term the thing most people are thinking about is tomorrow. They don't have much. If you ask someone on the factory floor if they know about marine phosphate mining they will, but the blue economy would not be a big concern of theirs. If marine phosphate mining happened, then they would just get jobs there. ${ }^{30}$

These identified structural constraints therefore limit the potential for the uptake of degrowth initiatives, despite incountry concerns reflecting the movements raison d'être.

While the blue economy agenda proclaims to enable states to access and economically benefit from the potential of their marine environment (African Union 2014), it is unlikely to lead to the equitable distribution of resource rents, due to inherent structural inequities, and it will not provide the all-encompassing solution to Namibia's current recession. Degrowth aims to rectify this potential unequal distribution of resources within and between countries (Demaria et al. 2013: 195), by downscaling production and consumption. This downscaling will complement the wider goal of safeguarding and improving ecological conditions at multi-scalar levels (Hadjimichael 2018). Namibia's experience with the green economy has been criticised for not actually leading to a redistribution of rents, something that several interviewees mentioned that they feared would be replicated by the blue economy. In Namibia there is concern that there will not be local ownership of projects and that the financial benefits will be extraterritorial or accrued to a handful of individuals with connections to the government.

In championing equal distribution and grassroots initiatives, the degrowth movement draws on initiatives such as Eco-Swaraj in India and Buen Vivir in Latin America. EcoSwaraj emerged from civil society to offer a framework that proposes to establish "a socio-cultural, political and economic arrangement in which all people and communities have the right and full opportunity to participate in decisionmaking, based on the twin fulcrums of ecological sustainability and human equity" (Dale et al. 2015; see also Kothari et al. 2014). Collectives and communities such as the Deccan Development Society in India's drylands of Andhra Pradesh are placed at the centre of environmental governance. Here, initiatives utilise organic farming, work to achieve food sovereignty, collectivise resources and labour and form cooperatives to ensure improvements in returns, moving away from

$\overline{30}$ Industry representative, Walvis Bay, Namibia, 2017. state or corporation-centric economic models (Dale et al. 2015). In Latin America, the concept of Buen Vivir (Good Life) is fluid and entwined with nature. It exists in opposition to models of accumulation and encompasses cultural diversity and community co-existence. Spiritual relations with the environment, human values and visions of the future are all considered within this paradigm (Kothari et al. 2014). However, owing in part to alternative movements' reliance on, and extrapolation of, these oft-cited examples, degrowth movements overlook the importance of local context(s) in the success of such initiatives. The prioritisation of local and grassroots initiatives and the democratic (re)distribution of resources asserted by the degrowth movement (see Chiengkul 2018) encounters issues when transposed to Namibia, particularly when considering the marine sphere.

While emerging discussions of blue degrowth highlight the grassroots counter-movements to marine mining in Papua New Guinea (see Hadjimichael 2018), the Namibian case highlights how civil society involvement is more complex and not homogenously representative of the Namibian populus. While protestation against seabed mining has been observed in Namibia, including protests from the Namibian Food and Allied Workers Union in 2016, and public mobilisation and media engagement by advocacy groups such as Swakopmund Matters, the space for formalised civil society has been reduced through the continuation of South West Africa People's Organisation (SWAPO)'s de facto one-party state.

Representatives of Namibia's formalised civil society spoke of an erosion of capacity and the need to build and reinforce institutions to support their ability to challenge projects such as marine phosphate mining. ${ }^{31}$ Similarly, the low levels of coastal habitation in Namibia and technologies and knowledges required to operate within the marine sphere, present challenges to those wishing to organise social movements. Simultaneously, by account of most Namibians physical distance from the sea, the marine scape is frequently forgotten in civic activism, and this presents obvious challenges to those wishing to mobilise citizens around issues related to the sea. However, the assumption, by degrowth movements, that local initiatives would ensure the democratic (re)distribution of resources rests on the hypothesis that civil society is representative of citizens' political sentiments and separate from the state (Van Rooy 1998a, b; Van Rooy and Robinson 1998). While civil society movements are campaigning against marine phosphate mining in Namibia, civil society remains dominated by elites,

\footnotetext{
31 Umbrella organisation representative, Windhoek, Namibia, 2018; Analyst, Windhoek, Namibia, 2018; NGO representative, Windhoek, Namibia, 2017.
} 
and the resultant fragmentation is exacerbated by additional divisions along racial lines.

There has been much interrogation of how civil society is conceptualised; Thania Paffenholz, for example, challenges Western actors for being blind "towards the dominant role of local elites [and] an overstating of local resistance" (2015: 858). Romanticising local civil society (Richmond 2011) ignores inherent divisions, including those along hierarchy, power and race, which perpetuate exclusion (Paffenholz 2015: 862). In Namibia, the continued dominance of white elites in the civil society sphere has been critiqued as perpetuating divisions and power structures, excluding alternative, and historically disenfranchised voices. Similarly, the binary of international and local is complicated in Namibia with relations sometimes indivisible. Industrial, and often internationally owned, fishery interests have been vocal against seabed mining and both through ministerial engagement and local NGOs and advocacy movements. It is therefore important that degrowth movements, in their prioritisation of local and grassroots movements, recognise intrinsic imbalances and relationships and question whose voices are being included and/or excluded through civil society representation.

Issues of representation must not only be considered at a grassroots level but also at the global level. Just as the blue economy can be critiqued for its European origins and dissemination through INGOs, resulting in reduced coherence, the degrowth movement also has similar provenance, consolidated at international conferences in Paris and Barcelona, although it draws on extraneous models such as the abovementioned Buen Vivir and Eco Swaraj movements. Degrowth is an inherently European concept, its discourse shaped primarily by Western academics (Weiss and Cattaneo 2017: 220). For discussions to progress, a more representative voice must be included, and this voice must extend beyond the Eurocentric discussion. The case of Namibia indicates that presently, development is regarded as paramount to the government and the blue economy offers an essential source of government funding in the current economic climate. However, this uptake comes with a degree of apprehension. Ministerial representatives and NGOs relayed the boredom with which such concepts were met in Namibia, particularly those concepts that originating in the West and with little Namibian ownership. This is particularly pertinent given Namibia's colonial experience. As one ministerial representative explained, "we won't let armchair activists in the West determine the extent to which we will be allowed to use our resources or not," 32 a sentiment that discussions of alternative movements would be wise to consider. Just as the blue economy can be criticised for the lack of local

$\overline{32}$ NGO representative, Windhoek, Namibia, 2017. ownership and meaning it commands, alongside the need to address structural issues and disparities, so can the concept of blue degrowth.

If a blue degrowth movement is to be coined, then the fledgling movement must consider the spatial and (geo)physical characteristics of the marine scape and the implications of this three-dimensional and dynamic space on access and control, its governance and ability of social movements to engage with the space. By establishing blue degrowth as compatible with, or complementary to, the degrowth movement, the division(s) between land and sea are perpetuated. The bifurcation of the concept of the economy into blue and green creates an inaccurate binary that fails to recognise the interlinked nature of these spaces and continued perceptions of policies that the ocean is disconnected from land. Discussions of blue degrowth must therefore become more introspective, questioning what bluing the (de)growth movement achieves. The terminology, reflective of that used by proponents of the blue economy, can be divisive and it further fractures critiques, thus distancing the discussion from the questions that must be asked about the global political economy.

\section{Conclusion}

Despite the acknowledgement that there is little global consensus attributed to the definition of the blue economy, the agenda is championed for its development potential by the African Union and subsequently, several African states including Namibia. Ambiguity over definitions has reduced Namibia's marine environment to a space in which actors can exert influence over and apportion in accordance with their own agendas, leaving the blue economy as a concept that can be utilised to justify emerging projects. The multitude of conflicting interests in the blue economy also serves to exclude actors from the marine space. As such, the blue economy's increasing formalisation is articulated unevenly in Namibia and has inherently political implications.

Ministerial, industry and civil society representatives alike explained the uncertainties that remain around Namibia's blue economy, not least because its open remit leaves it open to interpretation dependent upon actors' or organisations' reading of the agenda. Seabed mining highlights one of the diverging internal and external agendas that are utilising the concept of blue growth as rationale for perusing projects. However, while such projects profess to offer the promise of development and appeal to imaginations of states enacting sovereignty over their EEZs and the resources therein in isolation from external involvement, the subsequent conflicts that are emerging in the marine sphere indicate otherwise. 
This article argues that the critique of the blue economy should be applied to emerging blue degrowth discussions. While professing to offer an alternative rationale to blue growth, degrowth agendas have the potential to exhibit similar shortcomings. As demonstrated with reference to Namibia, contextual and historical issues need to be recognised, and their inherent and continued structural effects analysed. This is of importance when considering whose voices are represented or excluded by such agendas, complicated by the (geo)physical characteristics of the marine sphere. Finally, when looking to establish blue degrowth this article questions whether being divisive, between the blue and the green, serves to complicate discussions further.

Open Access This article is distributed under the terms of the Creative Commons Attribution 4.0 International License (http://creativeco mmons.org/licenses/by/4.0/), which permits unrestricted use, distribution, and reproduction in any medium, provided you give appropriate credit to the original author(s) and the source, provide a link to the Creative Commons license, and indicate if changes were made.

\section{References}

Abbott J, Anderson JL, Campling L, Hannesson R, Havice E, Lozier S, Wilberg MJ (2014) Steering the global partnership for oceans. Mar Res Econ 29(1):1-16

Adar K (1987) A note on the role of African states in committee I of UNCLOS III. Ocean Dev Int Law 18(6):665-681

African Union (2014) Agenda 2063. African Union Commission. http://archive.au.int/assets/images/agenda2063.pdf. Accessed 18 Dec 2019

Arkema K, Abramson S, Dewsbury B (2006) Marine ecosystem-based management: from characterisation to implementation. Front Ecol Environ 4(10):525-532

Bakker K (2010) Privatizing water. Governance failure and the world's urban water crisis. Cornell University Press, Ithaca

Ban NC, Bax NJ, Gjerde KM, Devillers R, Dunn DC, Dunstan PK, Halpin PN (2014) Systematic conservation planning: a better recipe for managing the high seas for biodiversity conservation and sustainable use. Conserv Lett 7(1):41-54

Barbier EB (2012) Scarcity, frontiers and development. Geogr J 178:110-122

Barca S (2019) The labor(s) of degrowth. Capital Nat Social 30(2):207-216

Belhabib D, Mendy A, Subah Y, Broh NT, Jueseah AS, Nipey N, Boeh WW, Willemse N, Zeller D, Pauly D (2016) Fisheries catch under-reporting in The Gambia, Liberia and Namibia and the three large marine ecosystems which they represent. Environ Dev 17(1):157-174

Boucquey N, Fairbanks L, St.Martin K, Campbell LM, McCay B (2016) The ontological politics of marine spatial planning: assembling the ocean and shaping the capacities of 'Community' and 'Environment'. Geoforum 75:1-11

Brand U, Wissen M (2012) Global environmental politics and the imperial mode of living. Articulations of state-capital relations in the multiple crisis. Globalizations 9:2

Campbell LM, Gray NJ, Fairbanks LW, Silver JJ, Gruby RL (2013) Oceans at Rio + 20. Conserv Lett 6(6):439-447
Carver R (2019) Resource sovereignty and accumulation in the blue economy: the case of seabed mining in Namibia. J Polit Ecol 26(1):381-402

Chalfin B (2015) Governing offshore oil: mapping maritime political space in Ghana and the Western Gulf of Guinea. S Atl Q 114(1):101-118

Chiengkul P (2018) The degrowth movement: alternative economic practices and relevance to developing countries. Alternatives 43(2):81-95

Childs J (2018) Extraction in four dimensions: time, space and the emerging geo(-)politics of deep-sea mining. Geopolitics 2018:1-25

Corson C (2010) Shifting environmental governance in a neoliberal world: US AID for conservation. Antipode 42(3):576-602

Dale G, Mathai MV, Puppim de Oliveira JA (2015) Green growth: ideology, political economy and the alternatives. Zed Books, London

Demaria F, Schneider F, Sekulova F, Martinez-Alier J (2013) What is degrowth? From an activist slogan to a social movement. Environ Values 22(2):191-215

Dodds K (2012) Graduated and paternal sovereignty: Stephen Harper, Operation Nanook 10, and the Canadian Arctic. Environ Plan D Soc Space 30(6):989-1010

Edwards M (2004) Civil society. Polity, Cambridge

Egede E (2014) The common heritage of mankind and the sub-saharan African Native land tenure system: a "clash of cultures" in the interpretation of concepts in international law? J Afr Law 2018:1-18

Erastus AN (2002) The Development of the Namibianisation Policy in the Hake Subsector, 1994-1999. In: The Namibian Economic Policy Research Unit (NEPRU) Research Report No. 82

European Commission (2019) Blue growth. https://ec.europa.eu/marit imeaffairs/policy/blue_growth_en. Accessed 25 Jun 2019

Faccer K, Nahman A, Audouin M (2014) Interpreting the green economy: emerging discourses and their considerations for the Global South. Dev South Afr 31(5):642-657

Fairhead J, Leach M, Scoones I (2012) Green Grabbing: a new appropriation of nature? J Peasant Stud 39(2):237-261

Findlay K (2018) Operation Phakisa and unlocking South Africa's ocean economy. J Indian Ocean Region 2013:412

Gazzola P, Roe M, Cowie P, Borzel T (2015) Marine spatial planning and terrestrial spatial planning: reflecting on new agendas. Env Plan C Government Policy 33(5):1156-1172

Gibson R (2002) Specification of sustainability-based environmental assessment criteria and implications for determining "significance" in environmental assessment. Canadian Environmental Assessment Agency, Ottawa

GLISPA (2018) Seychelles blue economy vision. http://www.glisp a.org/11-commitments/208-seychelles-blue-economy. Accessed 8 Feb 2019

Goodman J, Salleh A (2013) The 'green economy': class hegemony and counter-hegemony. Globalizations 10(3):411-424

Hadjimichael M (2018) A call for a blue degrowth: unravelling the European Union's fisheries and maritime policies. Mar Policy 194:158-164

Hannigan J (2016) The geopolitics of deep oceans. Polity Press, Cambridge

Jaeckel A, Ardon JA, Gjerde KM (2016) Sharing benefits of the common heritage of mankind-is the deep seabed mining regime ready? Mar Policy 70:198-204

Keane J (1998) Civil society: old images, new visions. Stanford University Press, Stanford

Khor M (2011) Risks and uses of the 'green economy' concept in the context of sustainable development, poverty and equity. South Centre, Geneva

Klinger J (2018a) Rare earth frontiers: from terrestrial subsoils to lunar landscapes. Cornell University Press, Ithaca, London 
Klinger J (2018b) Rare earth elements: development, sustainability and policy issues. Extr Ind Soc 5(1):1-7

Kothari A, Demaria F, Acosta A (2014) Buen vivir, degrowth and ecological swaraj: alternatives to sustainable development and the green economy. Development 57(3-4):362-375

Lapeyre R (2011) The Grootberg lodge partnership in Namibia: towards poverty alleviation and empowerment for long-term sustainability? Curr Issues Tour 14(3):221-234

Li TM (2007) The will to improve governmentality, development, and the practice of politics. Duke University Press, Durham

Lopes C (2016) Africa's blue economy: an opportunity not to be missed. https://www.uneca.org/es-blog/africa\%E2\%80\%99s-blueeconomy-opportunity-not-be-missed. Accessed 9 Dec 2018

Martínez-Alier J (2012) Environmental justice and economic degrowth: an alliance between two movements. Capital Nature Soc 23(1):51-73

Melber H (2003) From controlled change to changed control: the case of Namibia. J Contemporary Afr Stud 21(2):267-284

Melber H (2014) Understanding Namibia: the trials of independence. C Hurst \& Co Publishers Ltd, London

Morrissey K (2017) It's not just a Blue Economy moment.... Dialogues Hum Geogr 7(1):42-44

Morrissey K, O'Donoghue C, Hynes S (2011) Quantifying the value of multi-sectoral marine commercial activity in Ireland. Mar Policy 35(5):721-727

Müller M (2015) Assemblages and actor-networks: rethinking sociomaterial power, politics and space. Geogr Compass 9(1):27-41

Naidoo R, Weaver LC, Diggle RW, Matongo G, Stuart-Hill G, Thouless $\mathrm{C}$ (2016) Complementary benefits of tourism and hunting to communal conservancies in Namibia. Conserv Biol 30(3):628-638

Nyaungwa N, Winning A, Brock J (2018) UPDATE 1-Namibia drops into recession as construction, retail slump, Reuters. https:// www.reuters.com/article/namibia-gdp/update-1namibia-drops -into-recession-as-construction-retail-slump-idUSL8N1RB2FO. Accessed 7 Sep 2019

Paffenholz T (2015) Unpacking the local turn in peacebuilding: a critical assessment towards an agenda for future research. Third World Q 36(5):857-874

Perry V, Keil S (2013) The OSCE mission in Bosnia and Herzegovina: testing the limits of ownership. Natl Papers J Natl Ethnicity 41(3):71-394

Pinkerton E (2017) Hegemony and resistance: disturbing patterns and hopeful signs in the impact of neoliberal policies on small-scale fisheries around the world. Mar Policy 80:1-9

Republic of Namibia (2017) Namibia's 5th national development plan: working together towards prosperity 2017/18-2021/22. National Planning Commission, Windhoek. http://www.gov.na/docum ents/10181/14226/NDP+5/. Accessed 7 Feb 2019

Richmond O (2011) De-romanticising the local, de-mystifying the international: hybridity in Timor Leste and the Solomon Islands. Pac Rev 24(1):115-136

Rupple O, Baim D (2016) Taking back the seas: prospects for Africa's blue economy. In: Institute for Security Studies paper 290

Sammler K (2016) The deep pacific: island governance and seabed mineral development. In: Stratford E (ed) Island geographies: essays and conversations. Routledge, New York, pp 10-31

Sandberg M, Klockars K, Wilén K (2019) Green growth or degrowth? Assessing the normative justifications for environmental sustainability and economic growth through critical social theory. $\mathrm{J}$ Cleaner Prod 206:133-141

SBEC (2018) Report on the global sustainable blue economy conference. 26th-28th November 2018, Nairobi, Kenya. http://www. blueeconomyconference.go.ke/wp-content/uploads/2018/12/ SBEC-FINAL-REPORT-8-DECEMBER-2018-rev-2-1-2-PDF23-compressed.pdf. Accessed 24 Jun 2019

Schrijver NJ (1997) Sovereignty over natural resources. Balancing rights and duties. Cambridge University Press, Cambridge
Silver J, Gray N, Campbell L, Fairbanks L, Gruby R (2015) Blue economy and competing discourses in international oceans governance. J Env Dev 24(2):135-160

Sjöstedt M, Sundström A (2015) Coping with illegal fishing: an institutional account of success and failure in Namibia and South Africa. Biol Cons 189:78-85

Steinberg P (2008) 'It's so easy being green: overuse, underexposure, and the marine environmentalist consensus. Geogr Compass 2(6):2080-2096

Stoddart H (2011) A Pocket guide to sustainable de elopement governance. In: Stakeholder Forum

Stojanovic TA, Farmer C (2013) The development of world oceans $\&$ coasts and concepts of sustainability. Mar Policy 42:157-165

Suárez-de Vivero JL (2013) The extended continental shelf: a geographical perspective of the implementation of article 76 of UNCLOS. Ocean Coast Manag 73:113-126

Sullivan S, Hannis M, Impey A, Low C and Rohde RF (2016) Future pasts? Sustainabilities in west Namibia-a conceptual framework for research. In: Future Pasts Working Papers 1

UNECA (2016) Africa's blue economy: a policy handbook. Economic Commission for Africa, Addis Ababa. http://repository.uneca.org/ bitstream/handle/10855/23014/b11560836.pdf. Accessed 7 Feb 2019

UNEP (2011) Towards a green economy: pathways to sustainable development and poverty eradication-a synthesis for policy makers. United Nations Environment Programme, Nairobi. https ://sustainabledevelopment.un.org/content/documents/126GER_ synthesis_en.pdf. Accessed 8 Feb 2019

Van Rooy A (1998a) All roads lead to Rome. In: Van Rooy A (ed) Civil society and the aid industry: the politics and promise. Earthscan Publications, London, pp 1-5

Van Rooy A (1998b) Civil society as idea: an analytical hatstand? In: Van Rooy A (ed) Civil society and the aid industry: the politics and promise. Earthscan Publications, London, pp 6-30

Van Rooy A, Robinson M (1998) Out of the ivory tower: civil society and the aid system. In: Van Rooy A (ed) Civil society and the aid industry: the politics and promise. Earthscan Publications, London, pp 31-70

van Wyk J (2015) Defining the blue economy as a South African strategic priority: toward a sustainable 10th province? J Indian Ocean Region 11(2):153-169

Wanner T (2015) The new "passive revolution" of the green economy and growth discourse: maintaining the "sustainable development" of neoliberal capitalism. New Polit Economy 20(1):21-41

Weiss M, Cattaneo C (2017) Degrowth—taking stock and reviewing an emerging academic paradigm. Ecol Econ 137:220-230

Winder G, Le Heron R (2017) Assembling a Blue Economy moment? Geographic engagement with globalizing biological-economic relations in multi-use marine environments. Dialogues Hum Geogr 7(1):3-26

World Bank (2017a) What is the blue economy? http://www.world bank.org/en/news/infog raphic/2017/06/06/blue-economy. Accessed 30 Aug 2018

World Bank (2017b) The World Bank in Namibia. https://www.world bank.org/en/country/namibia. Accessed 26 Jun 2019

World Trade Organisation (2010) World Trade Report 2010, Trade in natural resources. WTO Publications. World Trade Organization. Switzerland

WWF (2013) Namibia's Sustainable Tourism Success, World Wildlife Fund, 29 October. https://www.worldwildlife.org/stories/namib ia-s-sustainable-tourism-success. Accessed 8 Feb 2019

Zhao R, Hynes S, He GS (2014) Defining and quantifying China's ocean economy. Mar Policy 43:164-173

Publisher's Note Springer Nature remains neutral with regard to jurisdictional claims in published maps and institutional affiliations. 